\title{
ROLE OF EXOPOLYMER AND ACID-TOLERANCE IN THE GROWTH OF BACTERIA IN SOLUTIONS WITH HIGH COPPER ION CONCENTRATION
}

\author{
W.-L. CHAO* AND CHERYL L. F. CHEN \\ Department of Microbiology, Soochow University, \\ Shih Lin, Taipei, Taiwan, Republic of China
}

(Received April 3, 1991)

\begin{abstract}
When copper-resistant Escherichia coli HB101 cells were transferred from regular to copper-amended, 1/3 strength Tryptic Soy Broth (TSB), there was an increase in the amount of exopolymer produced. The copper binding abilities of exopolymer for Pseudomonas aeruginosa 7, P. pseudomallei 13-1 (both copper-resistant) and from P. putida 3 (coppersensitive), were also determined. If treated with phenol, about 50 to $75 \%$ of the copper binding ability of these exopolymers was removed. Although the amount of copper ion bound by the exopolymer isolated from $P$. putida 3 was about the same as from the resistant organisms, it did not grow in medium containing $0.5 \mathrm{ppm}$ copper ion. When free copper ion concentration in $1 / 3$ strength TSB increased to $0.5 \mathrm{ppm}$, the $\mathrm{pH}$ value of the broth dropped from 6.8 to 4.9 . We believe this was what prevented the growth of the $P$. putida 3 in the solution containing the high concentration of copper ion.
\end{abstract}

Many metals (e.g., copper) when in low concentrations are essential for microbial growth but they become toxic in high concentrations. Some microorganisms, exposed to high levels of heavy metals, have evolved resistance mechanism (s), such as active exclusion (14), forming cysteine-rich proteins (8), increasing $\omega$-cyclohexyl fatty acids level in the membrane (12), detoxification by redox conversion (3), and producing hydrogen sulfide (6) and extracellular polysaccharide (1). This enables them to maintain their functions in the presence of high concentrations of heavy metals.

Low $\mathrm{pH}$ or high concentrations of metal ions inhibit various microbial activities. Also the solubility of metal increases as the $\mathrm{pH}$ of the solution decreases. Wastewater released from the plating industry has low acidity and high concentrations of metal ions. Yet, some bacteria do proliferate in them. Hence, we were curious to know what the major factor(s) are that allow them to do so.

* Address reprint requests to: Dr. Wei-Liang Chao, Department of Microbiology, Soochow University, Shih Lin, Taipei, Taiwan, R.O.C. 


\section{MATERIALS AND METHODS}

Bacterial strains. Heavy metal-resistant Pseudomonas spp. were isolated from the sediment of a ditch which had been receiving effluent from a metal processing plant for more than a decade. Samples were diluted in saline $(0.85 \% \mathrm{NaCl} ; \mathrm{w} / \mathrm{v})$ and plated on 1/3 strength Tryptic Soy Agar (TSA; Difco Laboratories, Detroit, MI, USA) plates containing different amounts of copper sulfate. The plates were then incubated in the dark at $30^{\circ} \mathrm{C}$ for $72 \mathrm{~h}$. Colonies were isolated and purified on the $1 / 3$ strength TSA plate amended with the same amount of copper sulfate. Bacteria which have high copper-resistant ability were selected for further study. Isolates 7 and 13-1 were identified as Pseudomonas aeruginosa and P. pseudomallei, respectively, by using API 20NE (38390 Montalieu-Vercieu, France). Spontaneous copper-resistant Escherichia coli HB101 was obtained by plating a cell suspension on copper-amended $1 / 3$ strength TSA plates. Pseudomonas putida 3 (coppersensitive) was obtained from the culture collection of the Department of Microbiology, Soochow University, Taipei, Taiwan, Republic of China.

Growth of the selected bacteria in the presence of copper ion. The concentration of copper ion in $1 / 3$ strength TSB medium was determined using a copper ion electrode (HNU Systems Inc., Newton Highlands, MA, USA), and adjusted to $0.001,0.01,0.5,1,2,3$, and $4 \mu \mathrm{g}$ per $\mathrm{ml}$ by increasing the amount of copper sulfate added. The media were then filter-sterilized and distributed aseptically into pre-sterilized glass test tubes. After inoculation with the selected bacteria, the tubes were then incubated at $30^{\circ} \mathrm{C}$ in a rotating tube shaker $(120 \mathrm{rpm})$ for $72 \mathrm{~h}$. The turbidity increase was determined by measuring the absorbance at $600 \mathrm{~nm}$ with a Spectrophotometer (Spectronic 20; Bausch \& Lomb, Analytical Systems Division, Rochester, NY, USA).

Copper-resistant Escherichia coli HB101 was first cultivated in the TSB medium overnight. Cells were then collected by centrifugation and washed with $0.85 \% \mathrm{NaCl}$ solution. The cell suspension was added to flasks containing the TSB medium with or without copper amendment, and their optical densities (at $600 \mathrm{~nm}$ ) were adjusted to 0.05 . These flasks were then incubated on a rotary shaker $(200$ $\mathrm{rpm})$ at $37^{\circ} \mathrm{C}$. The change in turbidity was measured as above.

Isolation of exopolymer. Pseudomonas spp., after different periods of incubation in the $1 / 3$ strength TSB medium at $30^{\circ} \mathrm{C}$ on a rotary shaker $(120 \mathrm{rpm})$, were harvested by centrifugation at $8,000 \times g$ for $10 \mathrm{~min}$ and washed three times with saline $(0.85 \% \mathrm{NaCl})$. The cell pellet was suspended in a solution consisting of 20 mM EDTA and $0.1 \mathrm{M}$ Tris- $\mathrm{HCl}(\mathrm{pH} \mathrm{7.0)}$ then mixed vigorously for $2 \mathrm{~min}$. The supernatant fluid was separated from cells by centrifugation at $8,000 \times g$ for $10 \mathrm{~min}$. Isopropyl alcohol was added to the above supernatant to a final concentration of $45 \%(\mathrm{v} / \mathrm{v})$ and placed at $4{ }^{\circ} \mathrm{C}$ for $36 \mathrm{~h}$. The precipitate was collected by centrifugation at $10,000 \times g$ for $15 \mathrm{~min}$. Alcohol was removed by heating this precipitate at $85^{\circ} \mathrm{C}$ overnight. This precipitate was then dissolved in distilled water and 
dialyzed against deionized water at $4^{\circ} \mathrm{C}$ for $24 \mathrm{~h}$. The insoluble material was removed by centrifuging at $20,000 \times g$ for $60 \mathrm{~min}$. The water in the above supernatant was removed by lyophilization. For copper-resistant $E$. coli, exopolymers were isolated from cultures that had reached an early stationary phase. Exopolysaccharides of Pseudomonas spp. were prepared by using phenol extraction to remove protein from the expolymers that had been isolated.

Copper ion binding by exopolymer. Known amounts of exopolymer were first dissolved in $5 \mathrm{ml}$ of deionized water prepared by using the Milli-Q water purification system (Millipore Corporation, Bedford, MA, USA). This solution was then added to $95 \mathrm{ml}$ of solution with known copper ion concentration. In the control experiment, $5 \mathrm{ml}$ of deionized water only was added to $95 \mathrm{ml}$ of the above copper ion solution. The copper ion concentration was measured with an ion electrode.

Growth of test bacteria in broth with different $\mathrm{pH}$ values. The $\mathrm{pH}$ value of $1 / 3$ strength TSB medium was adjusted to $5.5,5.0,4.5$, and 4.0 with $0.1 \mathrm{~N} \mathrm{HCl}$. These media were filter-sterilized and portions $(5.0 \mathrm{ml})$ of them were distributed into each of the pre-sterilized glass test tubes. The growth of the test bacteria in them was measured by the method mentioned above.

Relationship between copper ion concentration and the $\mathrm{pH}$ of the growth medium. Various amounts of copper sulfate were added to the $1 / 3$ strength TSB medium. The ionic concentration of copper in the medium and its $\mathrm{pH}$ were determined with an ion electrode and a $\mathrm{pH}$ meter, respectively.

\section{RESULTS}

Growth of bacteria in TSB medium amended with copper ion

When the actual copper ion concentration in the TSB medium varied from $0.001 \mu \mathrm{g}$ per $\mathrm{ml}$ to $4 \mu \mathrm{g}$ per $\mathrm{ml}$, growth of $P$. putida 3 occurred only in media containing copper ions up to $0.01 \mu \mathrm{g}$ per $\mathrm{ml}$. But $P$. aeruginosa 7 and $P$. pseudomallei 13-1 still grew in the presence of 3 and $4 \mu \mathrm{g}$ per $\mathrm{ml}$ of copper ion, respectively (Table 1).

Table 1. Growth of Pseudomonas spp. in Tryptic Soy Broth amended with different concentrations of copper ion.

\begin{tabular}{cccc}
\hline $\begin{array}{c}\text { Copper ion } \\
\text { concentration } \\
(\mu \mathrm{g} / \mathrm{ml})\end{array}$ & $\begin{array}{c}\text { Pseudomonas } \\
\text { putida } 3\end{array}$ & $\begin{array}{c}\text { Pseudomonas } \\
\text { aeruginosa } 7\end{array}$ & $\begin{array}{c}\text { Pseudomonas } \\
\text { pseudomallei } 13-1\end{array}$ \\
\cline { 2 - 4 } & + & + & + \\
0.001 & + & + & + \\
0.01 & - & + & + \\
1 & - & + & + \\
2 & - & + & + \\
3 & - & - & + \\
\hline
\end{tabular}




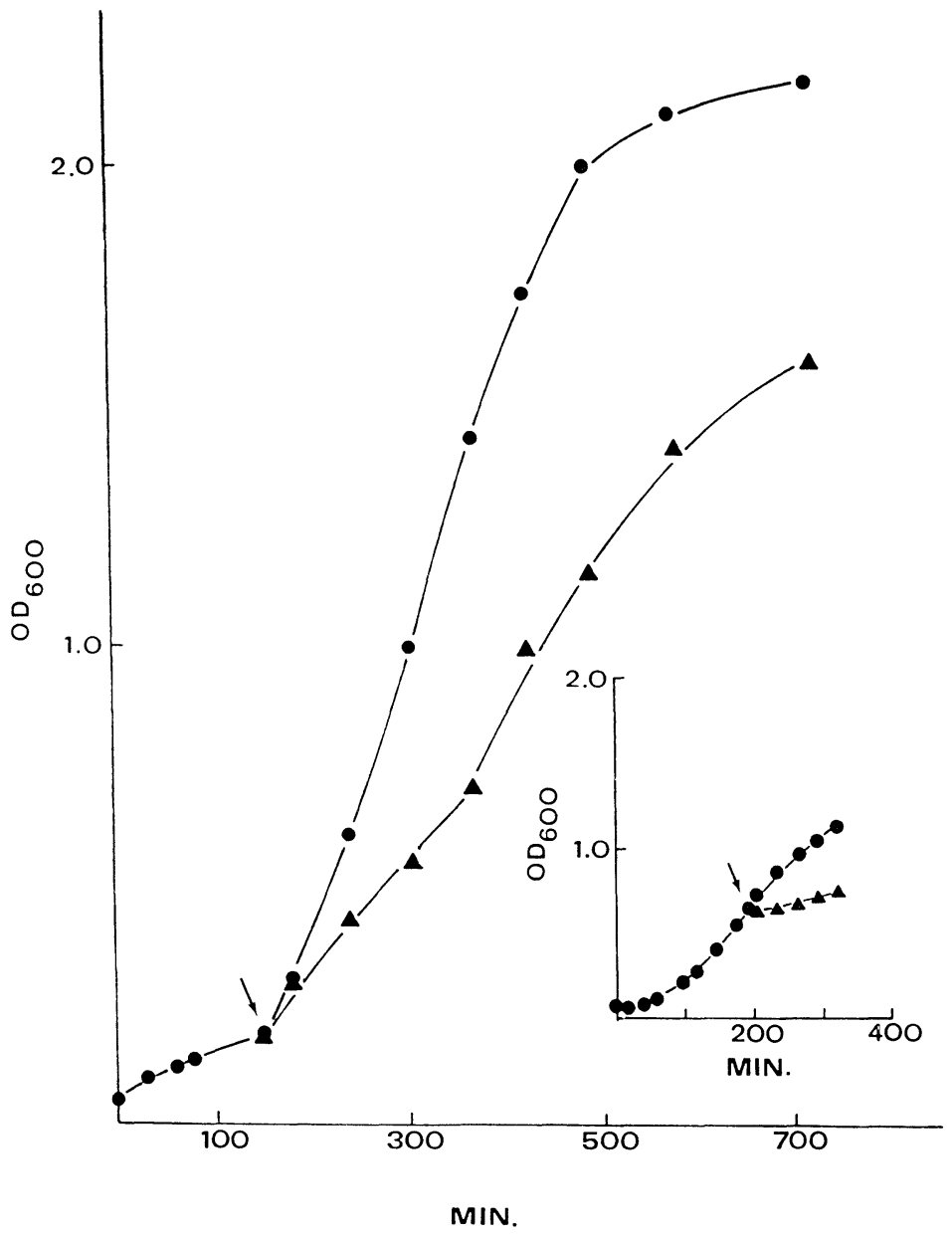

Fig. 1. Growth of copper-resistant E. coli in TSB medium. Without copper amendment $(\bullet)$, with copper amendment $(\mathbf{\Delta})$. Insert figure describes the growth of copper-sensitive $E$. coli in TSB medium with $(\mathbf{\Delta})$ or without $(\bullet)$ copper amendment. Arrow indicates copper sulfate was added.

When copper-resistant $E$. coli HB101 was inoculated into medium containing $100 \mathrm{ppm}$ of copper sulfate, there was a significant decrease in growth rate compared to the growth rate in the normal TSB broth (Fig. 1).

Binding of copper ion by exopolymers

As shown in Table 2, the amount of exopolymer produced by $P$. putida 3, $P$. aeruginosa 7, and $P$. pseudomallei 13-1 after incubation for $5 \mathrm{~h}$ was $580 \mu \mathrm{g}, 422 \mu \mathrm{g}$, and $70 \mu \mathrm{g}$ per $\mathrm{mg}$ of oven-dried cells, respectively. If the period of incubation was extended up to $24 \mathrm{~h}$, the amount of exopolymer produced by the above pseudo- 
Table 2. Binding of copper ion by exopolymers produced ${ }^{a}$ by Pseudomonas spp.

\begin{tabular}{lccc}
\hline Organism & $\begin{array}{c}\text { Incubation } \\
\text { period }(\mathrm{h})\end{array}$ & $\begin{array}{c}\text { Exopolymer produced } \\
(\mu \mathrm{g} / \mathrm{mg} \text { dried cell })\end{array}$ & $\begin{array}{c}\text { Copper ion bound } \\
(\mu \mathrm{g} / \mathrm{g} \text { exopolymer })\end{array}$ \\
\hline P. putida 3 & 5 & 580 & $127(66)^{b}$ \\
P. aeruginosa 7 & 24 & 94 & $106(40)$ \\
& 5 & 422 & $125(67)$ \\
P. pseudomallei $13-1$ & 24 & 118 & $84(60)$ \\
& 5 & 70 & $107(39)$ \\
& 24 & 61 & $98(\mathrm{ND})^{c}$
\end{tabular}

a Average of three samples.

$b$ Binding of copper ion by phenol-treated exopolymers.

c $\mathrm{ND}=$ Not done.

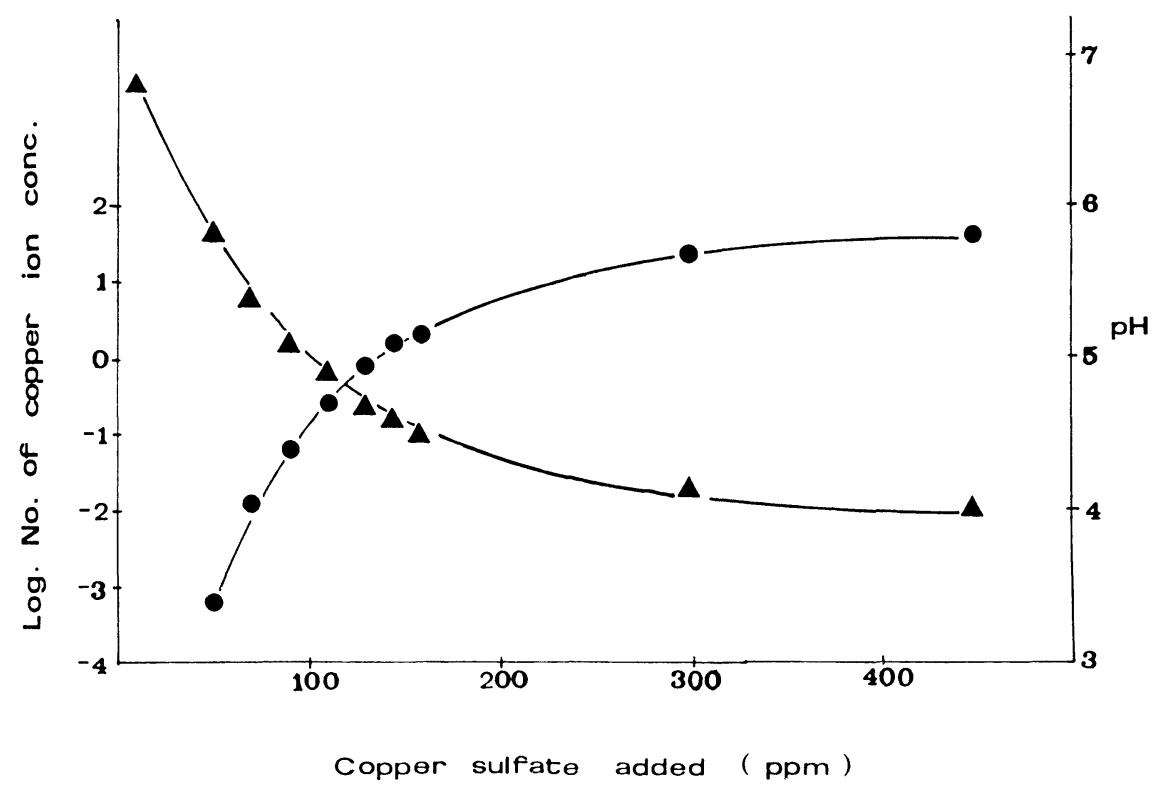

Fig. 2. Relationship between copper ion concentration $(\bullet)$ and the pH $(\Delta)$ of the growth medium.

monads was $94 \mu \mathrm{g}, 118 \mu \mathrm{g}$, and $60 \mu \mathrm{g}$ per mg of oven-dried cells, respectively. The copper ion binding ability of the exopolymer produced by each of the Pseudomonas spp. after different periods of incubation were about the same. The only exception was that after incubation for $24 \mathrm{~h}$ the copper ion binding ability of the exopolymer produced by $P$. aeruginosa 7 was lower than the others (Table 2). If treated with phenol, about $50 \%$ of the copper ion binding ability of exopolymers isolated from $P$. putida 3 and $P$. aeruginosa 7 was lost and $70 \%$ was lost from the exopolymer isolated from $P$. pseudomallei 13-1.

When copper-resistant E. coli HB101 were inoculated into media with or 
Table 3. Growth of Pseudomonas spp. in Tryptic Soy Broth with different $\mathrm{pH}$ values.

\begin{tabular}{cccc}
\hline & \multicolumn{3}{c}{ Pseudomonas species } \\
\cline { 2 - 4 } & $\begin{array}{c}\text { Pseudomonas } \\
\text { putida } 3\end{array}$ & $\begin{array}{c}\text { Pseudomonas } \\
\text { aeruginosa } 7\end{array}$ & $\begin{array}{c}\text { Pseudomonas } \\
\text { pseudomallei } 13-1\end{array}$ \\
\hline 5.5 & + & + & + \\
5.0 & + & + & + \\
4.5 & - & + & + \\
4.0 & - & - & + \\
\hline
\end{tabular}

without copper supplement and incubated for $5.5 \mathrm{~h}$, the amounts of exopolymer produced were $533 \mathrm{ng}$ and $206 \mathrm{ng}$ per $\mathrm{mg}$ of cell, respectively.

Relationship between copper ion concentration and $\mathrm{pH}$ of the growth medium

The copper ion concentrations in the growth medium measured by the ion electrode was significantly different from the actual amount of copper sulfate added. When the amount of added copper sulfate increased from $10 \mu \mathrm{g}$ per $\mathrm{ml}$ to $100 \mu \mathrm{g}$ per $\mathrm{ml}$, the $\mathrm{pH}$ of the growth medium decreased from 6.8 to 5.0. As the amount of copper sulfate added increased from $100 \mu \mathrm{g}$ per $\mathrm{ml}$ to $450 \mu \mathrm{g}$ per ml, the subsequent $\mathrm{pH}$ of the growth medium only decreased from 5.0 to 4.0 (Fig. 2).

Growth of the test bacteria in media with different $p H s$

When $P$. pseudomallei 13-1, P. aeruginosa 7, and P. putida 3 were inoculated into TSB media of different $\mathrm{pHs}$, the lowest $\mathrm{pH}$ that they could proliferate at were 4.0, 4.5, and 5.0, respectively (Table 3).

\section{DISCUSSION}

It is well known that microorganisms are responsible for many important processes, including nutrient cycling, in the environment. When they are under stress, these functions might be hindered and cause some unfavorable effect on the balance of the ecosystem $(2,7,11)$. For bacteria to grow in the presence of heavy metal, one of the methods adapted was to prevent the metals from entering into their cytoplasm, as in forming metal-binding protein or exopolysaccharide. Mittelman and Geesey (10) reported that exopolysaccharide from a bacterial strain isolated from the metal-laden sediment of a freshwater river, bound up to $253 \mathrm{~nm}$ of copper ion per $\mathrm{mg}$ of carbohydrate. In this study, there was a significant increase in the amount of exopolymer produced by the copper-resistant $E$. coli when this bacterium was grown in copper-amended medium as compared to the normal medium. But when comparing the copper binding abilities of the exopolymers isolated from either copper-resistant or copper-sensitive pseudomonads, the differences are too small to account for the former's copper-resistant ability. When exopolymer was treated with phenol to remove protein, about 50 to $75 \%$ of the 
copper-binding capacity of the exopolymer was also removed. However, the copper binding abilities of the remaining exopolysaccharide still did not account for the differences in copper resistance among pseudomonads tested.

From the results reported by various researchers, it is clear that the total amount of heavy metals in the environment does not always coincide with the extent of their toxicities $(4,5,7,13)$. It was shown that the toxicity of copper to the estuarine microbial community was a quantitative function of free copper ion activity (9). Acidity $(\mathrm{pH})$ is one of the factors which affects the solubility of heavy metals. Consequently, in a solution, the concentration of heavy metals increased as the $\mathrm{pH}$ decreased. We have observed a close relationship between the abilities of the test organisms to grow in medium with low $\mathrm{pH}$ and their ability to tolerate high levels of copper ion. Clearly, the growth of the Pseudomonas spp. used in this study, in the presence of copper ion were not related to either the amount of exopolymer produced or to the copper ion binding ability of these exopolymers, but to their abilities to tolerate the acidity of the surrounding environment. Therefore, for microorganisms to proliferate properly in environments containing high concentrations of copper ion, they must first overcome the limitation of acidity before various protective mechanisms (e.g., producing copper ion binding exopolymer) are turned on.

This work was supported by the National Science Council, Republic of China, grant NSC77-0414B031-01Z, NSC78-0421-B031-01Z.

\section{REFERENCES}

1) Bitton, G. and Freihofer, V., Influence of extracellular polysaccharide on the toxicity of copper and cadmium towards Klebsiella aerogenes. Microb. Ecol., 4, 119-125 (1978).

2) Chang, F. H. and Broadbent, F. E., Influence of trace metals on some soil nitrogen transformations. J. Environ. Qual., 11, 1-4 (1982).

3) Chiong, M., Gonzalez, E., Barra, R., and Vasquez, C., Purification and biochemical characterization of tellurite reducing activities from Thermus thermophilus HB8. J. Bacteriol., 170, 32693273 (1988).

4) Dean-Ross, D., and Mills, A. L., Bacterial community structure and function along a heavy metal gradient. Appl. Environ. Microbiol., 55, 2002-2009 (1989).

5) Doelman, P. and Haanstra, L., Effect of lead on soil respiration and dehydrogenase activity. Soil Biol. Biochem., 11, 475-479 (1979).

6) Ehrlich, H. L. and Fox, S. I., Copper sulfide precipitation by yeasts from acid mine-waters. Appl. Microbiol., 15, 135-139 (1967).

7) Hattori, H., Influence of cadmium on decomposition of sewage sludge and microbial activities in soils. Soil Sci. Plant Nutr., 35, 289-299 (1989).

8) Higham, D. P., Sadler, P. J., and Scawen, M. D., Cadmium-resistant Pseudomonas putida synthesizes novel cadmium proteins. Science, 225, 1043-1046 (1984).

9) Jonas, B. B., Acute copper and cupric ion toxicity in an estuarine microbial community. Appl. Environ. Microbiol., 55, 43-49 (1989).

10) Mittelman, M. W. and Geesey, G. G., Copper-binding characteristics of exopolymers from a freshwater-sediment bacterium. Appl. Environ. Microbiol., 49, 846-851 (1985). 
11) Naidu, C. K. and Reddy, T. K. R., Effect of cadmium on microorganisms and microbe-mediated mineralization process in the soil. Bull. Environ. Contam. Toxicol., 41, 657-663 (1988).

12) Ohya, H. and Komai, Y., Zinc uptake of Curtobacterium possessing $\omega$-cyclohexyl fatty acids and zinc-binding activity of its membrane. FEMS Microbiol. Lett., 51, 163-168 (1988).

13) Sunda, W. G. and Gillespie, P. A., The response of a marine bacterium to cupric ion and its use to estimate cupric ion activity. J. Mar. Res., 37, 761-777 (1979).

14) Tynecka, Z., Gos, Z., and Zajac, J., Energy-dependent efflux of cadmium coded by a plasmid resistance determinant in Staphylococcus aureus. J. Bacteriol., 147, 313-319 (1981). 